\title{
PENERAPAN SISTEM MANAJEMEN KESELAMATAN DAN KESEHATAN KERJA (SMK3) PT. INDOPHERIN JAYA
}

\author{
Aprillinardi Mahdi Putra Prasetya* \\ *Program Studi S1 Kesehatan Masyarakat Fak. Kesehatan Masyarakat, Universitas Airlangga \\ Email: redsunsholic93@gmail.com
}

\begin{abstract}
This research was intend to analyze whether implementation of occupational health and safety management system in PT. Indopherin Jaya have matched due to requirements of the Government regulation No. 50 in 2012. This research was a descriptive research. Subjects in this study were the auhority which has responsibility in the implementation of OHSMS namely P2K3L with amount of 8 people. The data were gained by interview and study of documents. The results showed that company had policy and commitment to OSH. Company also have done risk potential hazard identification when formulating a plans. Monitoring and evaluation of OSH performance had been implemented due to government regulation. OSH had been reviewed and improved routinely and sustainable. Company had implemented 95\% from all criteria OHSMS assessment due to Government regulation No. 50 in 2012.
\end{abstract}

Keywords: OHSMS (Occupational Health and Safety Management System), Phenolic Resin

\section{ABSTRAK}

Penelitian ini bertujuan untuk menganalisis apakah penerapan SMK3 PT. Indopherin Jaya telah sesuai dengan PP No. 50 Tahun 2012. Penelitian ini bersifat deskriptif. Subjek pada penelitian ini adalah pihak yang berwenang dalam penerapan SMK3 yakni anggota departemen P2K3L perusahaan sebanyak 8 orang. Data diperoleh dengan cara wawancara dan studi dokumen. Hasil penelitian menunjukkan bahwa PT. Indopherin Jaya telah memiliki kebijakan dan komitmen K3. Perumusan perencanaan berdasarkan identifikasi potensi bahaya. Pemantauan dan evaluasi telah dilakukan menurut ketentuan perundangan. Peninjauan dan peningkatan kinerja SMK3 juga sudah dilakukan secara rutin dan berkesinambungan. . PT. Indopherin Jaya sudah menerapkan 95\% dari semua kriteria pada penilaian penerapan SMK3 menurut PP No. 50 Tahun 2012.

\section{Kata Kunci : SMK3 (Sistem Manajemen Keselamatan dan Kesehatan Kerja), Resin fenolik}

\section{PENDAHULUAN}

Menurut riset yang diadakan oleh organisasi perburuhan dunia ILO 2013 bahwa setiap hari sekitar 6.300 orang mati kecelakaan kerja dan penyakit akibat kerja, setara dengan satu orang tiap 15 detik atau sekitar 2,3 juta orang per tahun. Kecelakaan dan cedera akibat kerap kali terjadi terutama di negara berkembang, dimana sebagian besar pekerjanya terlibat dalam aktivitas berbahaya seperti, pertambangan, sektor migas, industri bahan kimia, dan sebagainya. Dampak yang ditimbulkan dari kecelakaan ini meliputi direct cost, atau disebut sebagai biaya langsung yaitu biaya yang dapat dihitung secara langsung dari mulai terjadi peristiwa sampai dengan tahap rehabilitasi meliputi: biaya $\mathrm{P} 3 \mathrm{~K}$, biaya pengobatan dan perawatan, biaya angkut dan rumah sakit, biaya kompensasi asuransi kecelakaan, hingga upah selama tidak mampu bekerja sedangkan indirect cost atau biaya tidak langsung yaitu biaya yang dikeluarkan meliputi sesuatu yang tidak terlihat pada waktu kecelakaan maupun setelah kecelakaan yang meliputi: hilangnya waktu kerja, terhentinya proses produksi, kerusakan mesin hingga biaya untuk penyelidikan kecelakaan . Oleh karena itu bukan tidak mungkin bahwa hal yang selanjutnya terjadi yakni penurunan kuantitas produksi perusahaan, yang akan berdampak pada rendahnya produktivitas (HSA, 2006).
Sistem Manajemen Keselamatan dan Kesehatan Kerja yang selajutnya disingkat menjadi SMK3 menurut PP No. 50 Tahun 2012 merupakan bagian dari sistem manajemen perusahaan secara keseluruhan dalam rangka pengendalian risiko yang berkaitan dengan kegiatan kerja guna terciptanya tempat kerja yang aman, efisien, dan produktif. Sedangkan menurut OHSAS 18001 adalah merupakan manajemen sistem risiko $\mathrm{K} 3$ yang berhubungan dengan bisnis organisasi, dari sini dapat ditarik kesimpulan bahwa tujuan dari penerapan SMK3 baik itu OHSAS 18001 maupun PP No. 50 Tahun 2012 adalah bertujuan sama yakni untuk mengendalikan risiko yang berkaitan dengan K3 di perusahaan.

Upaya yang sudah dilakukan PT. Indopherin Jaya agar risiko kecelakaan bisa ditekan serendah-rendahnya yakni telah diberlakukannya sistem manajemen keselamatan dan kesehatan kerja (SMK3) di PT. Indopherin Jaya yang berstandarkan pada OHSAS 18001:2007, hal ini merupakan upaya PT. Indopherin Jaya dalam memenuhi pasar internasional untuk ekspor ke luar negeri yang mensyaratkan agar produk ekspor yang dikirim oleh PT. Indopherin Jaya supaya dipasang label keamanan produk berdasarkan standar OHSAS 18001.

Penelitian yang akan dilaksanakan di PT. Indopherin Jaya akan menggunakan standar PP No. 50 Tahun 2012 karena elemen yang ada di PP No. 50 Tahun 2012 memiliki 
kesamaan dengan OHSAS 18001 : 2007 yakni elemen kebijakan $\mathrm{K} 3$, perencanaan $\mathrm{K} 3$, pelaksanaan rencana $\mathrm{K} 3$, pemantauan dan evaluasi kinerja $\mathrm{K} 3$, peninjauan dan peningkatan kinerja SMK3, serta penilaian pencapaian implementasi SMK3 perusahan.
Penelitian ini bertujuan untuk mengevaluasi sejauh mana penerapan SMK3 yang sudah dilaksanakan oleh PT. Indopherin Jaya dengan menggunakan standar PP No. 50 Tahun 2012 .

Gambar 1. Grafik kecelakaan di PT. Indopherin Jaya 1996-2013

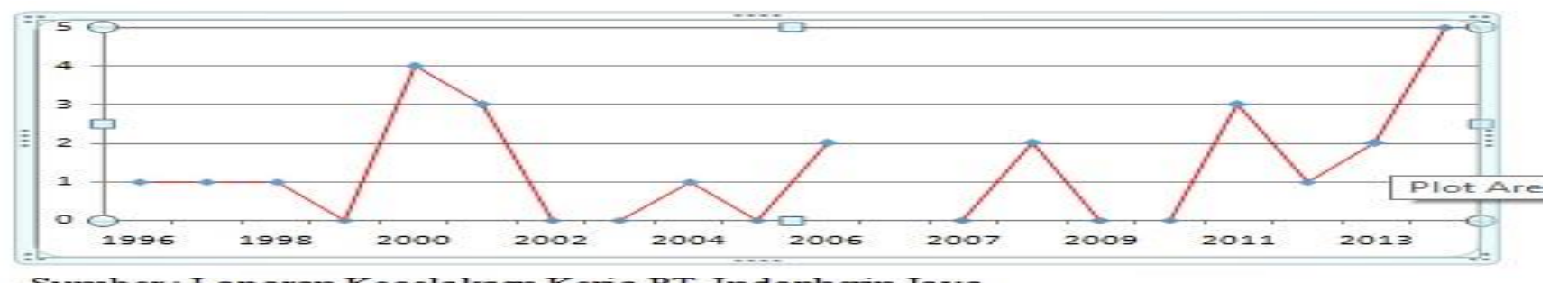

Sumber: data sekunder

\section{METODE}

Penelitian dilakukan secara observasional, dan pengambilan data dilakukan secara Survey terhadap informan perusahaan. Informan dalam penelitian ini adalah pihak yang berwenang terhadap penerapan SMK3 di perusahaan, yakni anggota $\mathrm{P} 2 \mathrm{~K} 3 \mathrm{~L}$ yang berjumlah 8 orang yang meliputi :
Sekretaris P2K3L, Koordinator Umum, Koordinator Shift 2 orang, Team Patrol, Team P3K, Team Emergency, dan Team Keamanan.

Penelitian ini dilaksanakan di PT. INDOPHERIN JAYA, Jl. BRANTAS No.1, Probolinggo. Penelitian dan pengambilan data dilaksanakan sejak bulan September sampai Oktober 2014. Variabel penelitian sebagai berikut :

Tabel 1. Variabel Penelitian
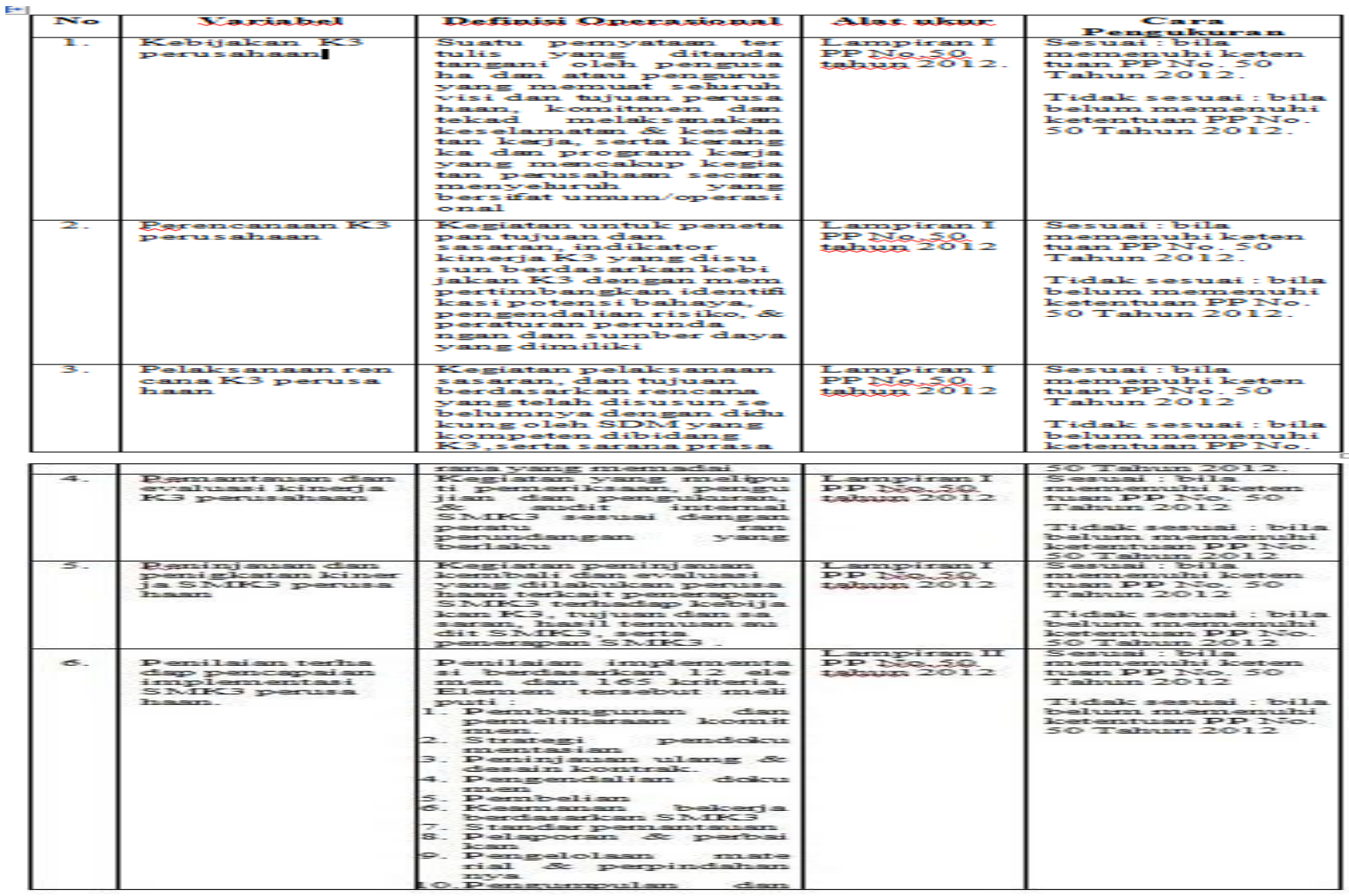

Sumber: data sekunder 
Data yang dikumpulkan dalam penelitian ini berupa data primer yang diperoleh melalui wawancara dengan pihak yang berwenang dalam penerapan SMK3 Pertanyaan yang diajukan adalah seputar kebijakan dan komitmen K3, perencanaan $\mathrm{K} 3$, pelaksanaan rencana $\mathrm{K} 3$, pemantauan dan evaluasi kinerja K3, dan Peninjauan dan peningkatan kinerja SMK3 perusahaan. Wawancara dilakukan selama 10-15 menit di ruangan responden. Selain itu digunakan pula lembar observasi yang digunakan untuk menilai pencapaian implementasi SMK3 yang terdiri dari 12 elemen dan 165 kriteria berdasarkan acuan lampiran II PP No. 50 Tahun 2012.

Data sekunder diperoleh melalui dokumentasi kegiatan yang dimiliki oleh perusahaan yang meliputi:Kebijakan K3 perusahaan, Data pelatihan K3 perusahaan,

Data instruksi kerja perusahaan, Daftar HIRA (Hazard Identification Risk Assessment) perusahaan,

\section{HASIL}

PT. Indopherin Jaya sudah memiliki Sistem Manajemen Keselamatan dan Kesehatan Kerja yang

\section{Kebijakan dan Komitmen K3}

Menurut hasil wawancara yang dilakukan terhadap 8 responden departemen $\mathrm{P} 2 \mathrm{~K} 3 \mathrm{~L} 8$ responden menyatakan bahwa PT. Indopherin Jaya telah memiliki komitmen dan
Standar Patrol, Alur identifikasi bahaya, Form MSDS (Material Safety Data Sheet) perusahaan, Lembar identifikasi bahaya, Data laporan K3 perusahaan, dan Laporan audit internal perusahaan. Instrumen yang digunakan untuk pengumpulan data adalah dengan mengunakan lampiran I PP No. 50 Tahun 2012 yang diperoleh melalui wawancara dan juga lampiran II PP No. 50 Tahun 2012 yang sudah ada dalam bentuk lembar observasi. Sedangkan untuk data sekunder diperoleh dari dokumentasi baik itu berupa dokumen tertulis maupun gambar.

Data yang telah diperoleh diolah dan dianalisis secara deskriptif, kemudian hasilnya disajikan dalam bentuk narasi, gambar, maupun tabel. Pengolahan dan analisis data dihubungkan dengan lampiran I dan II PP No.50 Tahun 2012.

berstandarkan pada OHSAS 18001:2007 Sedangkan hasil penelitian menggunakan standar PP No. 50 tahun 2012 adalah sebagai berikut :

kebijakan terhadap K3 seperti yang disyaratkan oleh perundangan, hal ini dibuktikan dengan adanya Form Policy yang ada seperti gambar berikut:

Gambar 2. Kebijakan PT. Indopherin Jaya

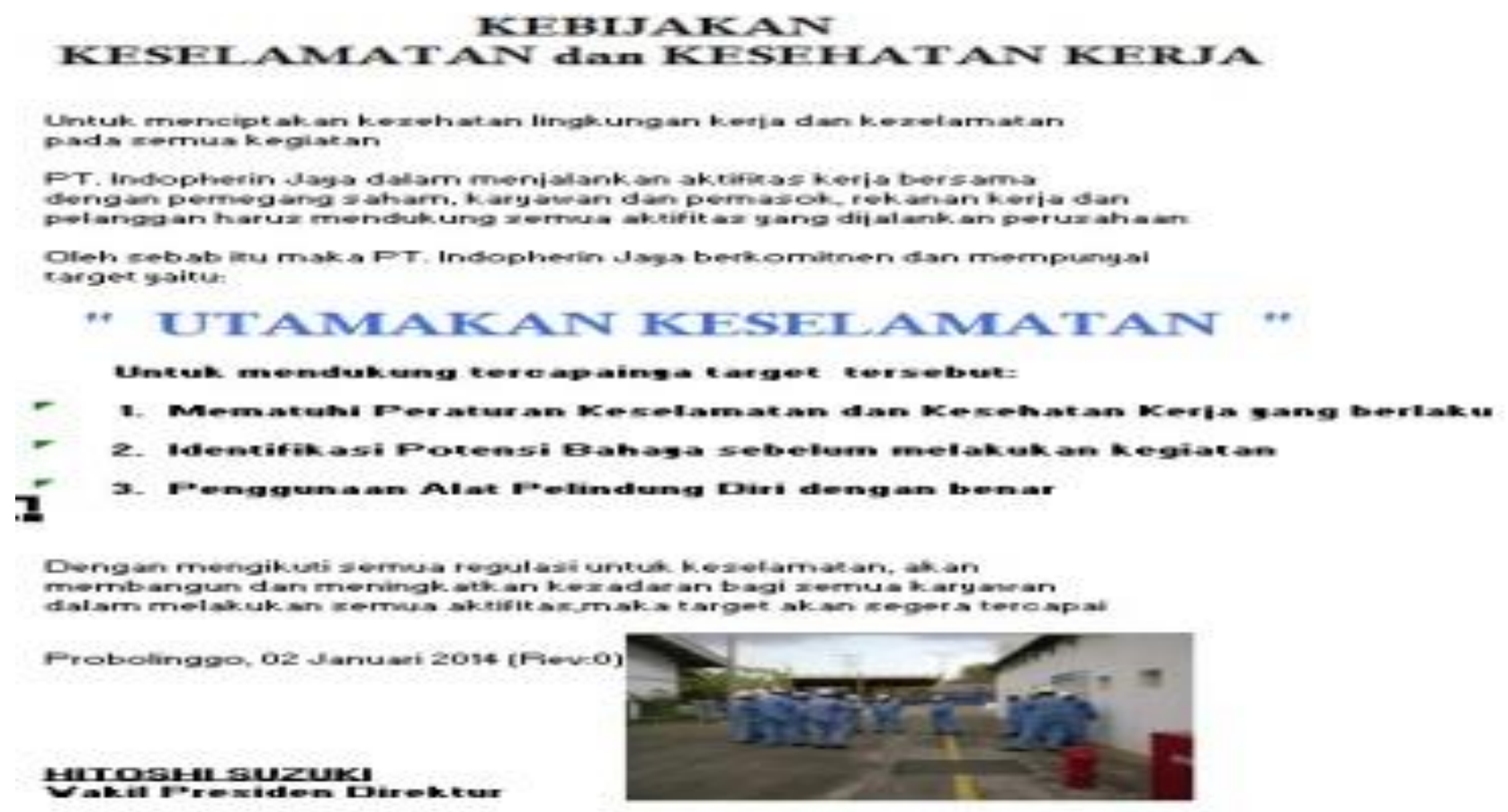

Sumber: data sekunder

Menurut responden PT. Indopherin Jaya dalam menyusun kebijakan K3 selalu mengutamakan tinjauan awal kondisi K3 seperti identifikasi potensi bahaya, alur identifikasi bahaya yang ada di PT. Indopherin Jaya sebagai berikut: 
Gambar 3. Alur Identifikasi Bahaya

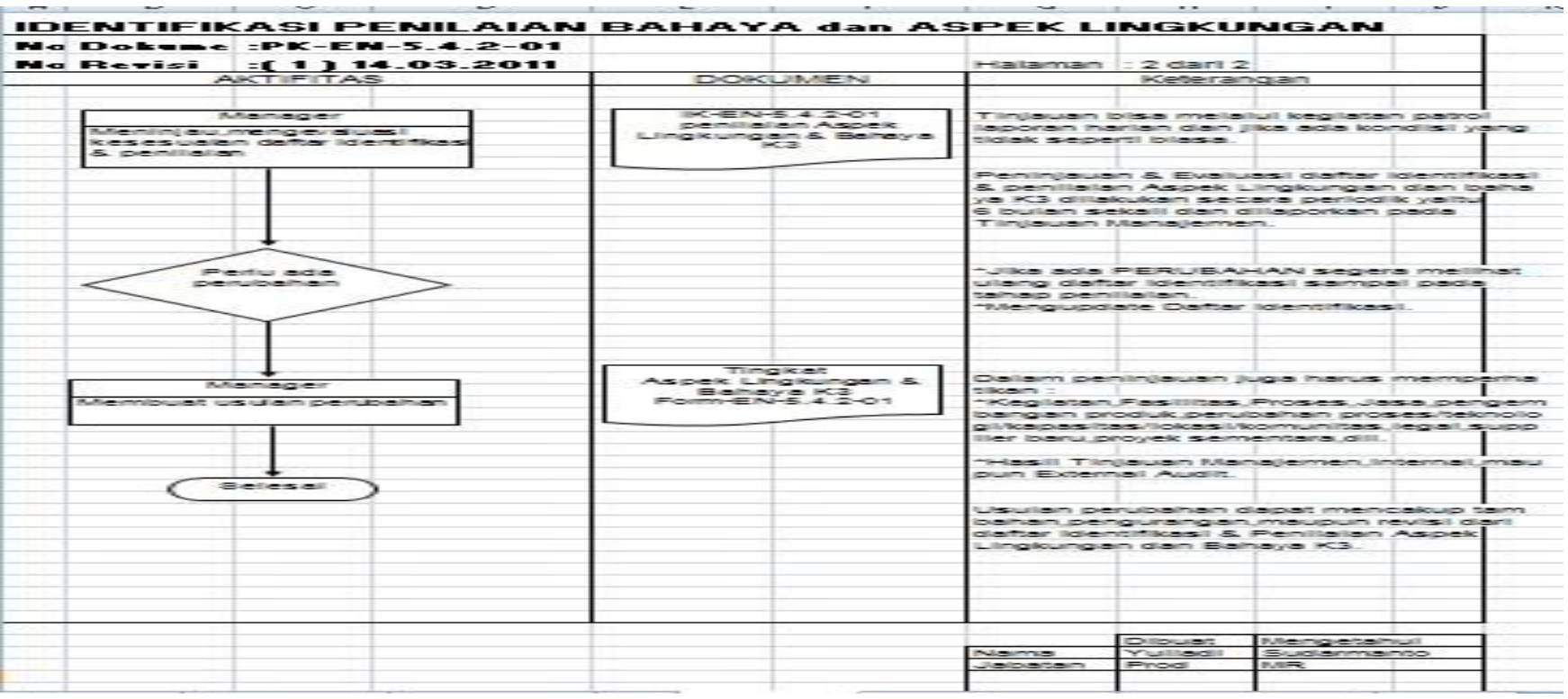

Sumber: data sekunder

Selain PT. Indopherin Jaya memiliki alur dan prosedur dalam menghadapi bahaya, PT. Indopherin Jaya juga memiliki lembar untuk mengidentifikasi bahaya untuk seluruh tingkatan kerja yang ada di perusahaan. Lembar tersebut adalah sebagai berikut:

Gambar 4. Lembar Identifikasi Bahaya

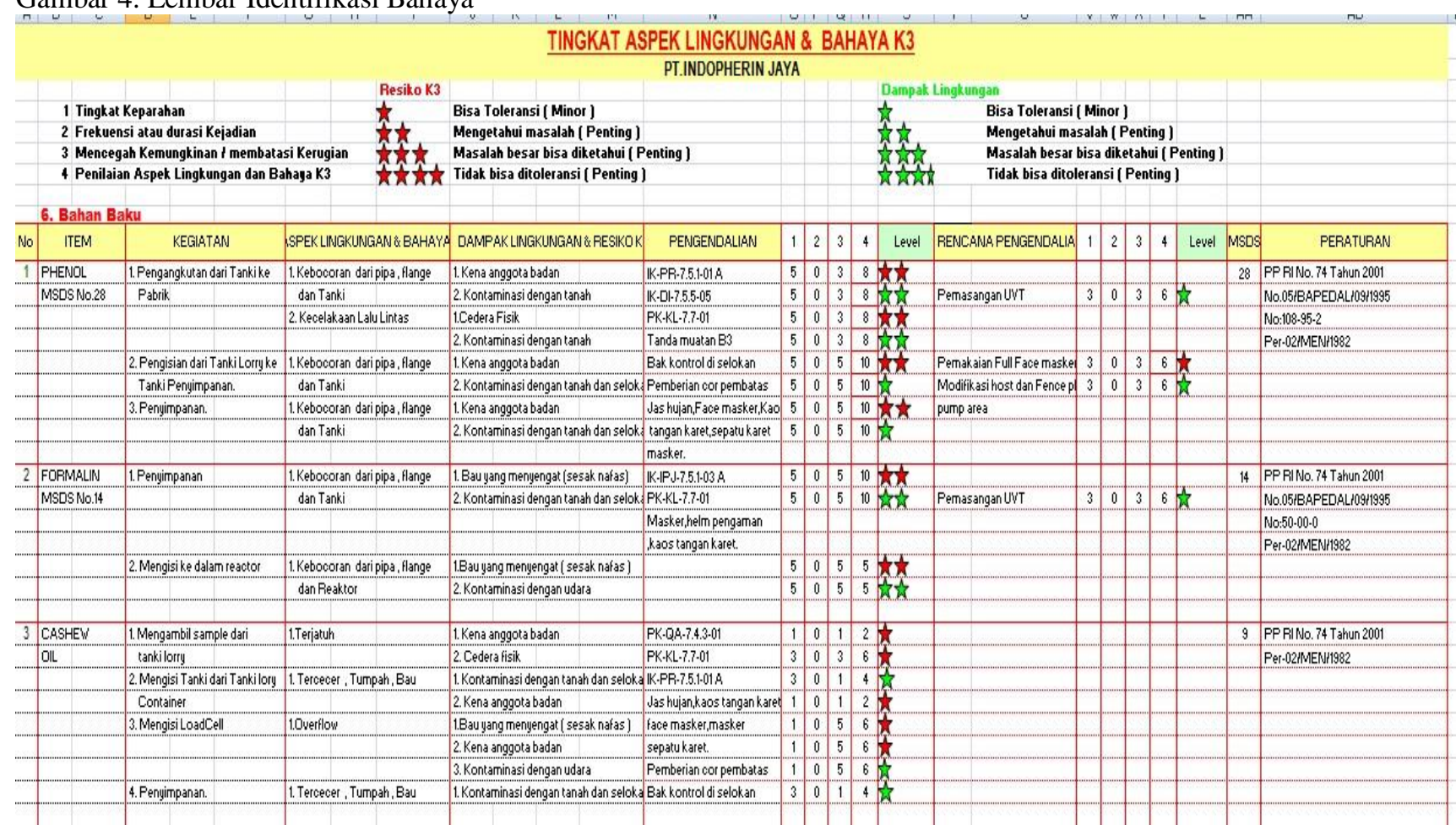

Sumber: data sekunder

Wakil presiden direktur juga sudah mengesahkan dan menandatangani kebijakan perusahaan berkaitan dengan Keselamatan dan Kesehatan Kerja untuk menciptakan lingkungan kerja sehat dan keselamatan pada setiap kegiatan dituangkan dalam bentuk poster yang ditandatangani oleh pimpinan yang tertera pada gambar sebagai berikut 
Gambar 5. Poster Kebijakan Perusahaan

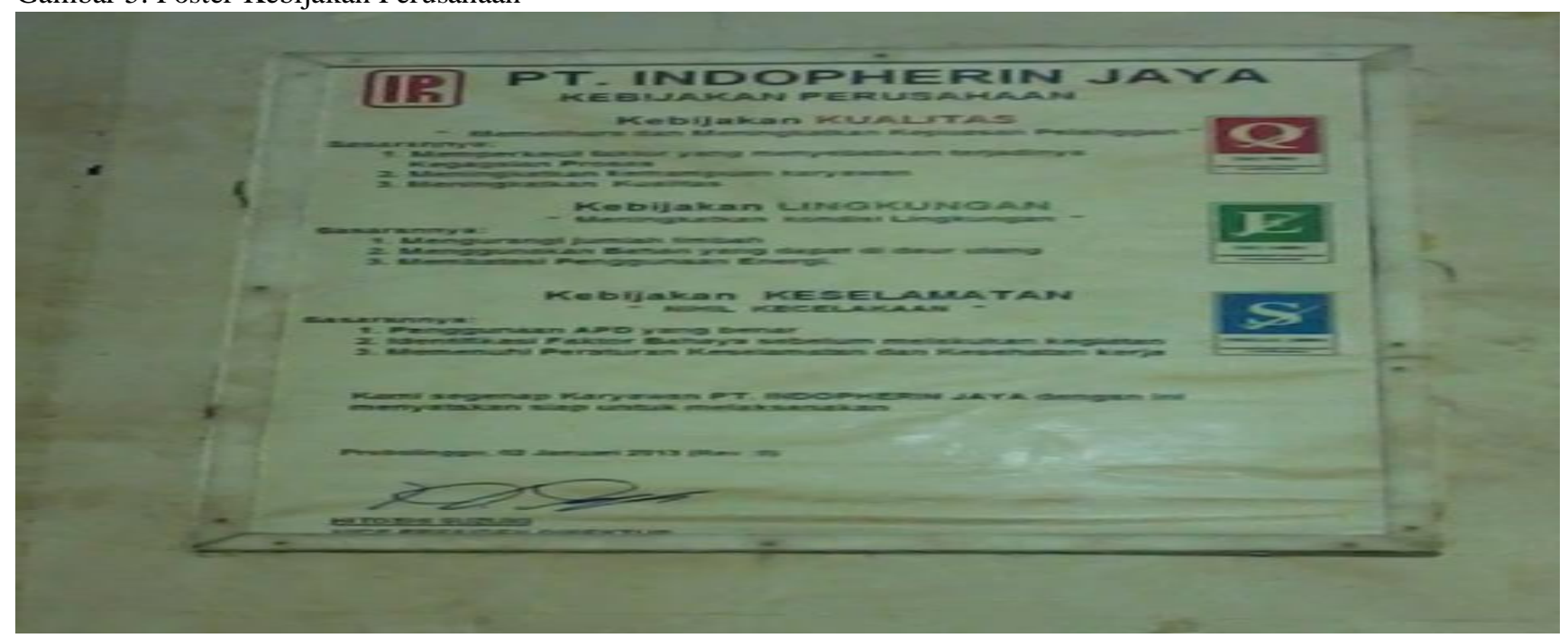

Sumber: data sekunder

Responden menyatakan kebijakan K3 perusahaan juga telah diinformasikan kepada tamu, kontraktor, pemasok, maupun pengunjung perusahaan. Hal ini dibuktikan dengan adanya pemberian safety instruction setiap kali memasuki area perusahaan. Kebijakan K3 terdokumentasi dan dipelihara dengan baik dan selalu dilakukan peninjauan secara rutin setiap tahun menyesuaikan perubahan yang terjadi di perusahaan maupun dalam peraturan perundangan. SMK3 perusahaan sudah terintegrasi dengan bagian perusahaan lainnya seperti bagian kualitas dan lingkungan memakai metode IMS (Integrated Management System). Penilaian kinerja sudah dilakukan dengan diadakan audit internal dan eksternal oleh lembaga tersertifikasi.

\section{Perencanaan K3}

Gambar 6. Standar Patrol PT. Indopherin Jaya
Menurut hasil wawancara yang dilakukan terhadap 8 responden mengenai perencanaan $\mathrm{K} 3$ di perusahaan, 8 responden menyatakan bahwa PT. Indopherin Jaya telah melakukan perencanaan K3 sesuai dengan peraturan perundangan, menurut responden PT. Indopherin Jaya dalam menyusun rencana K3 selalu berdasarkan:

\section{Hasil penelaahan awal}

PT. Indopherin Jaya dalam membuat perencanaan K3 selalu berdasarkan hasil penelaahan awal dengan cara melakukan tinjauan awal kondisi K3 perusahaan untuk menjamin dan meningkatkan lingkungan kerja yang aman dan bersih. Hal ini dibuktikan dengan dokumen yang mengatur standar pemeriksaan berupa patroli yang diperiksa oleh tim P2K3L perusahaan setiap hari sebelum melakukan aktivitas. Prosedur tersebut yaitu:

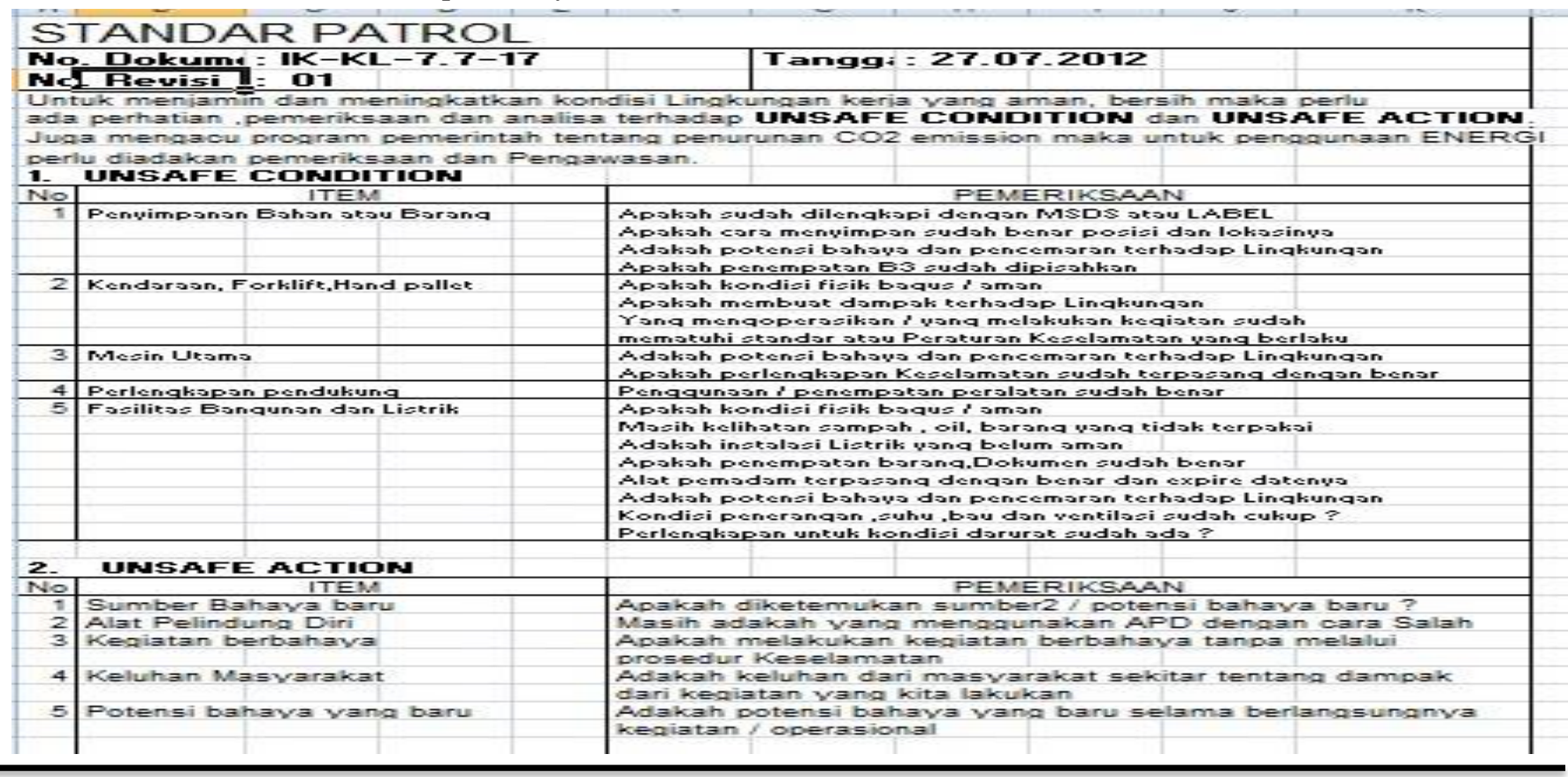

Corresponding Author: Aprillinardi Mahdi Putra Prasetya,

Penerapan Sistem Manajemen Keselamatan dan Kesehatan Kerja (SMK3) di PT. Indopherin Jaya 
JPH RECODE Vol. 1 No. 1 (2017)

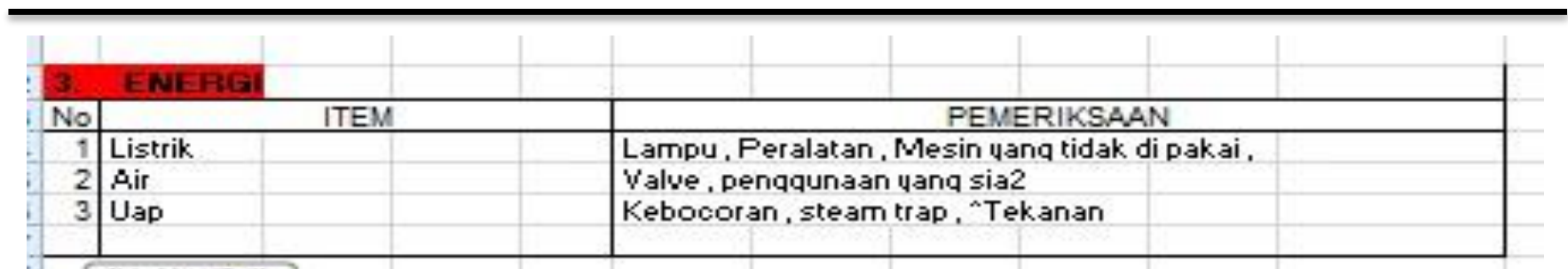

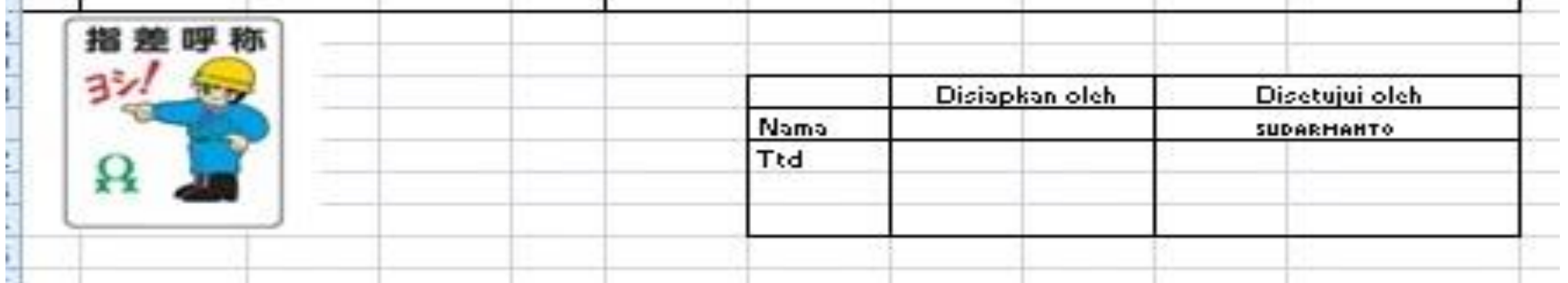

Sumber: data sekunder

Selain itu dilakukan pula identifikasi potensi bahaya, penilaian, dan risiko (Form HIRA) yang berisi risiko K3 dan dampaknya terhadap lingkungan meliputi tingkat keparahan, frekuensi atau durasi kejadian, dan penilaian aspek lingkungan dan bahaya $\mathrm{K} 3$, seperti yang terdapat pada penjelasan sebelumnya.

\section{Tinjauan perundangan}

PT. Indopherin Jaya memiliki dokumen tentang peraturan perundangan yang sesuai dengan bidang usaha dan bisnis perusahaan, perundangan telah disosialisasikan kepada seluruh pekerja oleh sekretaris perusahaan yakni oleh manajer representatif per usahaan yang memiliki sertifikat ahli K3 perusahaan.

\section{Sumber daya perusahaan}

PT. Indopherin Jaya dalam menyusun perencanaan telah mempertimbangkan sumber daya manusia meliputi tersedianya sumber daya manusia yang kompeten, sarana dan prasarana dan dana yang dimiliki perusahaan. Selain itu menurut responden, rencana K3 yang ada di PT. Indopherin Jaya meliputi:

\section{Tujuan dan sasaran}

PT. Indopherin Jaya dalam menetapkan tujuan dan sasaran selalu ditinjau kembali secara teratur sesuai dengan perkembangan teknologi dan peraturan perundangan terkini. PT. Indopherin Jaya memiliki target yakni "Utamakan Keselamatan" dan juga beberapa tujuan agar target tersebut bisa dicapai sesuai yang diharapkan, tujuan tersebut diantaranya : Meningkatkan kemampuan karya wan, evaporator, membatasi limbah solid, meningkatkan hari tanpa kecelakaan (Action Plan 2013, PT.Indopherin Jaya )

\section{Skala prioritas}

PT. Indopherin Jaya dalam menetapkan skala prioritas selalu berdasarkan tingkat risiko, dimana pekerjaan yang mempunyai tingkat risiko tinggi diprioritaskan dalam perencanaan seperti yang tertera pada Form RA (Risk Assessment) berikut:
Gambar 7. Form Pengisian RA

\begin{tabular}{|c|c|c|c|c|c|c|}
\hline 1 & 1 & 0 & $!$ & $i$ & 6 & $H$ \\
\hline [Fonn I & & & & & & \\
\hline Narrowing down 1SO environ & Inmental aspects / registere & $\operatorname{red~list|\| .}$ & |Evaluati & ation of g & gravity of & if consequence \\
\hline 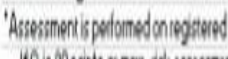 & 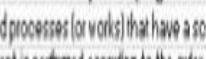 & roverd po & ponsisonor & & & \\
\hline 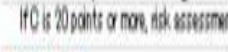 & 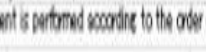 & Wothantis & & & & \\
\hline Bahan Batu & & & & & & \\
\hline 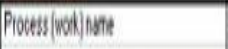 & 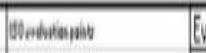 & Evaluingen & signated & demenes: & 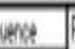 & $\sqrt{\text { Pioin) }}$ \\
\hline & & (1) & Q8 & (7) & 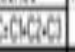 & \\
\hline Plinen & & & & & & \\
\hline 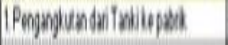 & 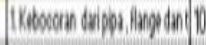 & 1010 & 10 & $0 \mid 30$ & D & \\
\hline & 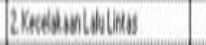 & & & & & \\
\hline 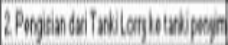 & 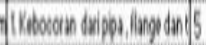 & in & $0 \mid 5$ & $8 x$ & $x$ & \\
\hline APenewen & 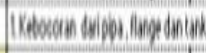 & & & & & \\
\hline POOMLAN & & & & & & \\
\hline Prepevin & 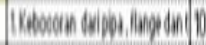 & & f & x & $y$ & \\
\hline 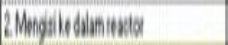 & 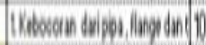 & & 5 & め & D & \\
\hline Suriacico & & & & & & \\
\hline IPrepenun & Itexace & & & & & \\
\hline & ituenelopoin & & & & & \\
\hline 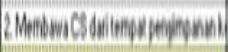 & lifenestionin & & & & & \\
\hline ESPHEOA & & & & & & \\
\hline 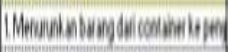 & 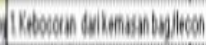 & & & & & \\
\hline 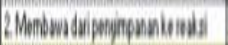 & itineationon & & & & & \\
\hline 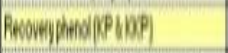 & & & & & & \\
\hline 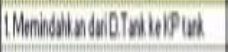 & 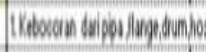 & & & & & \\
\hline Lipentugy & limph & & & & & \\
\hline PreNa IN & & & & & & \\
\hline |Fumbugng & Itrensumpon & & & & & \\
\hline DXACACOO & & & & & & \\
\hline 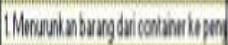 & therocoun ariby & & & & & \\
\hline SHACACACO & & & & & & \\
\hline 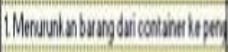 & thetocoun driby & & & & & \\
\hline 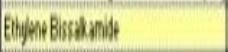 & & & & & & \\
\hline 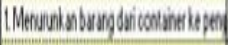 & theteoun wibly & & & & & \\
\hline EEROACOCO & & & & & & \\
\hline 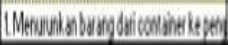 & Hetowan asiby & & & & & \\
\hline
\end{tabular}

Sumber: data sekunder 


\section{Upaya pengendalian bahaya}

PT. Indopherin Jaya memiliki prosedur dalam pengendalian bahaya yang dilakukan berdasarkan hasil penilaian risiko melalui pengendalian teknis, administratif, alat pelindung diri.

\section{Penetapan sumber daya}

PT. Indopherin Jaya dalam menyusun perencanaan telah mempertimbangkan sumber daya manusia meliputi tersedianya sumber daya manusia yang kompeten, sarana dan prasarana, dana yang dimiliki perusahaan.

\section{Jangka waktu pelaksanaan}

PT. Indopherin Jaya dalam merencanakan kegiatan K3 selalu mencantumkan jangka waktu pelaksanaan untuk setiap kegiatan yang dicanangkan seperti yang terdapat pada HSE (Health and Safety Environtment) Training Schedule seperti berikut :

Gambar 8. HSE Training Schedule ichedule Safetry Taun 20.14

\begin{tabular}{|c|c|c|c|c|}
\hline \multirow{2}{*}{ 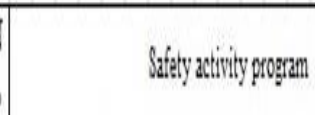 } & Jamzin & Penxai & Nyet & Apal \\
\hline & & & & \\
\hline \multicolumn{5}{|l|}{ Sdery meting } \\
\hline & & & & \\
\hline \multicolumn{5}{|l|}{ 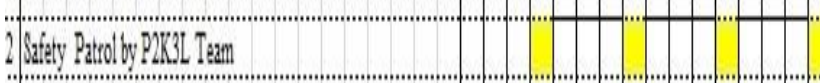 } \\
\hline & & & & \\
\hline \multicolumn{5}{|l|}{3 Satry, Badth Eboution Triming } \\
\hline \multicolumn{5}{|l|}{ 3I!LODS } \\
\hline \multicolumn{5}{|l|}{ 3.2. Fint ad } \\
\hline \multicolumn{5}{|l|}{3.3 Emygney furespon } \\
\hline & & & & \\
\hline \multicolumn{5}{|l|}{ 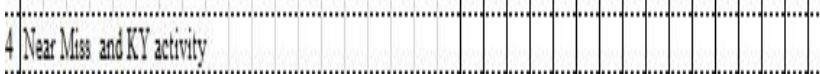 } \\
\hline \multicolumn{5}{|l|}{ 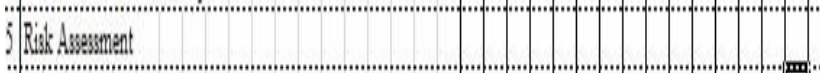 } \\
\hline & & & & \\
\hline & & & & \\
\hline & & & & \\
\hline & & & & \\
\hline & & & & \\
\hline
\end{tabular}

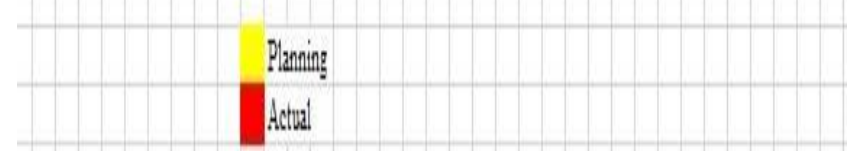

Sumber: data sekunder

\section{Sistem pertanggung jawaban}

PT. Indopherin Jaya dalam menetapkan pertanggung jawaban terhadap rencana K3 telah disesuaikan dengan fungsi dan tingkat manajemen perusahaan yang bersangkutan untuk menjamin perencanaan tersebut dapat dilaksanakan. Penanggung jawab mengenai pelaksanaan K3 perusahaan adalah adalah sekretaris P2K3L yakni Manager Representatif, dalam program pertanggung jawaban tersebut meliputi:

Safety meeting, kegiatan ini dilakukan setiap hari di ruangan rapat kerja P2K3L yang dihadiri oleh seluruh jajaran perusahaan dilakukan 30 menit sebelum pekerjaan dimulai. Safety Patrol, kegiatan ini dilaksanakan pada saat kegiatan produksi dimulai yang dilakukan oleh tim P2K3L PT.Indopherin Jaya. Setiap temuan ketidaksesuaian seperti Unsafe Action dan Unsafe Act akan segera dilaporkan kepada manager representatif yang kemudian akan ditindaklanjuti oleh atasan. Safety, Health Education training, kegiatan ini dilaksanakan setiap 3 bulan sekali, pelatihan ini mencakup pemahaman mengenai MSDS (Material Safety Data Sheet) atau Lembar Bahan Kimia Berbahaya, First Aid atau yang biasa disebut sebagai P3K, dan Emergency Fire Respon yakni respon tanggap darurat terhadap kebakaran.

\section{Pelaksanaan rencana $\mathrm{K} 3$}

Pelaksanaan rencana K3 dilakukan oleh PT. Indopherin Jaya sebagai bentuk dari perencanaan K3 yang telah dilakukan sebelumnya, Menurut hasil wawancara yang dilakukan terhadap 8 responden mengenai pelaksanaan rencana K3 di PT. Indopherin Jaya 7 dari 8 responden menyatakan bahwa pelaksanaan rencana K3 perusahaan telah sesuai dengan ketentuan perundangan, Bentuk pelaksanaan rencana K3 di PT. Indopherin Jaya sebagai berikut:

\section{Pengadaaan sumber daya manusia}

PT. Indopherin Jaya dalam hal pengadaan sumber daya manusia di bidang K3 ditetapkan berdasarkan standar kompetensi kerja yang diperoleh melalui pendidikan, pelatihan, keahlian yang dibutuhkan bagi setiap pekerjaan. Motivasi telah dibentuk yang diberikan perusahaan baik melalui pelatihan maupun pemberian kegiatan untuk mendapatkan sertifikat dalam bidang tertentu,. Tanggung jawab dan tanggung gugat dalam pelaksanaan K3 sudah dibentuk perusahaan dengan adanya departemen $\mathrm{P} 2 \mathrm{~K} 3 \mathrm{~L}$.

\section{Organisasi K3}

PT. Indopherin Jaya memiliki sarana dan prasarana berupa organisasi yang bertanggung jawabdi bidang K3 yang bernama P2K3L (Panitia Pembina Keselamatan dan Kesehatan Kerja dan Lingkungan). PT. Indopherin Jaya membentuk P2K3L sejak tahun 2007 dan sudah diperbarui pada tanggal 6 januari 2013. Tugas dan Fungsi P2K3L ini adalah untuk wadah kerjasama antara pengusaha dan tenaga kerja untuk mengembangkan kerja sama saling pengertian 
JPH RECODE Vol. 1 No. 1 (2017)

dan partisipasi efektif dalam penerapan SMK3. Struktur P2K3L di PT. Indopherin Jaya adalah sebagai berikut.

Gambar 9. Struktur P2K3L

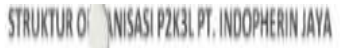
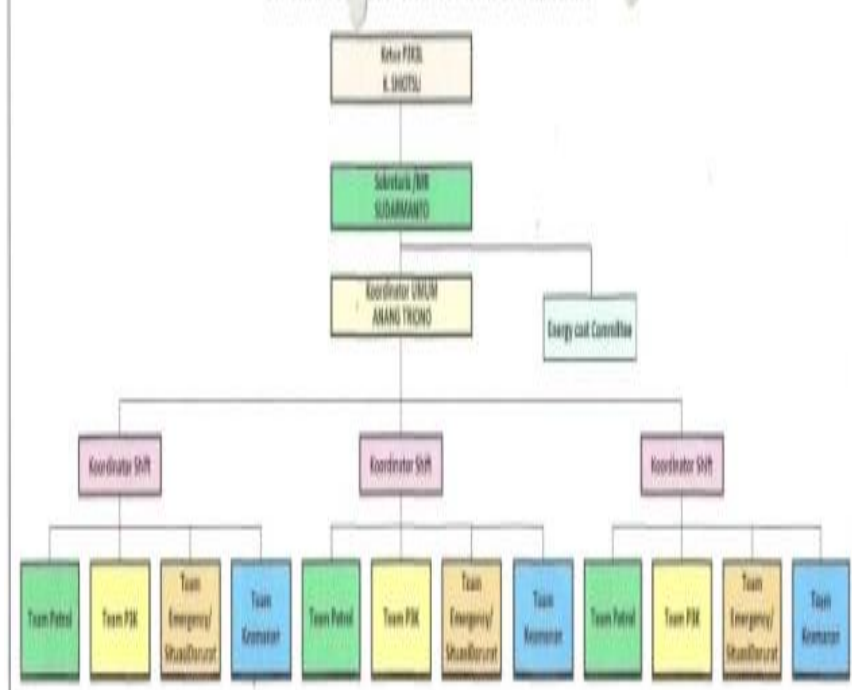

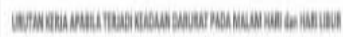

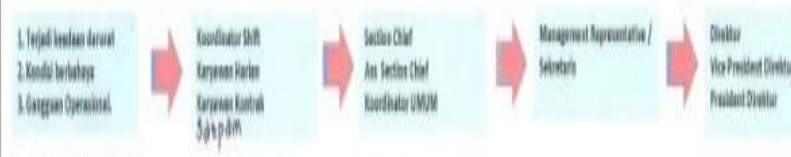

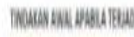

\begin{tabular}{|c|c|c|c|c|}
\hline 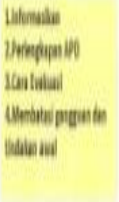 & t & \multicolumn{2}{|c|}{ 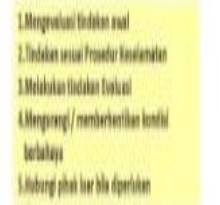 } & \\
\hline \multicolumn{5}{|c|}{ 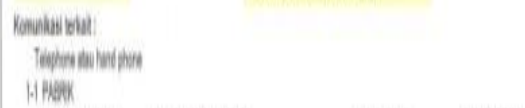 } \\
\hline Hexpen man. & ostor of & & Dethith & mowants \\
\hline AMI & A4694 & & Ham & 1609606 \\
\hline Koves & misien & & tepal & wrom \\
\hline Hail & 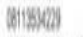 & & How & 18186001 \\
\hline West: & oxean of & 1110000 & & \\
\hline ingenten & OES 006 I I & 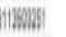 & 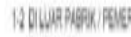 & NIN \\
\hline vaptow: & 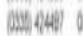 & WYy & fabsen & Giiit) \\
\hline mex & 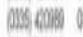 & HINASA & Newase & Qitil \\
\hline Whaten & misexing & & Hesto & gilli \\
\hline mentegre. & $\operatorname{arcos}$ & & Nin & Q1110 \\
\hline mistor: & Wabin & & 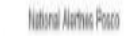 & 12.148 \\
\hline Wwat: & W285118 & & & \\
\hline Wayd: & wasum & & & \\
\hline vilis. & Miskory : & HIBOWy & & \\
\hline tenew & Masesu & & & \\
\hline Bitheneth & Q821506 & & & \\
\hline
\end{tabular}

Sumber: data sekunder

\section{Anggaran}

PT. Indopherin Jaya memiliki anggaran untuk menyediakan sarana dan prasarana K3 seperti sarana tanggap darurat dan peralatan pelindung diri, sarana dan prasarana tersebut antara lain:

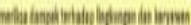

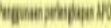

Unateonit

Waicunquablo

Chem

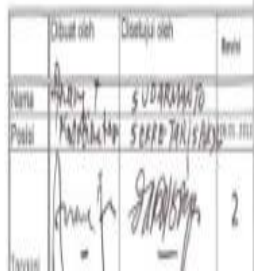

Tabel 2. Sarana Tanggap Darurat PT.

Indop herin Jaya

\begin{tabular}{|c|c|c|c|}
\hline No & Sarana Tanggap Darurat & Jumlah & Referensi Dokumen \\
\hline $\bar{A}$ & APAR & & \\
\hline 1 & Gardu PLN & t Unt & \multirow{8}{*}{$\begin{array}{l}\text { PerMenaker } \\
\text { No.41920 } \\
\text { Tentang } \\
\text { Syarat-6yarat } \\
\text { Penasangan } \\
\text { dan Pemeina } \\
\text { raan APAR }\end{array}$} \\
\hline 2 & Ganeraior 1 \& 2 Sama & 1Unt & \\
\hline 3 & Depan Cabinet No 1 & 1 Unit & \\
\hline 4 & Lantal 1 Reakior & $1 \mathrm{Unit}$ & \\
\hline 5 & Lantal 1 Area Puheryzer 1 & 1 Unt & \\
\hline 6 & Lantal 1 Area Pulveryzer 1 & 1 Unt & \\
\hline 7 & Pintu Besar Selatan & 1 Unit & \\
\hline 8 & Lantal 1 Area Pulvervzer 2 & 1 Unit & \\
\hline
\end{tabular}
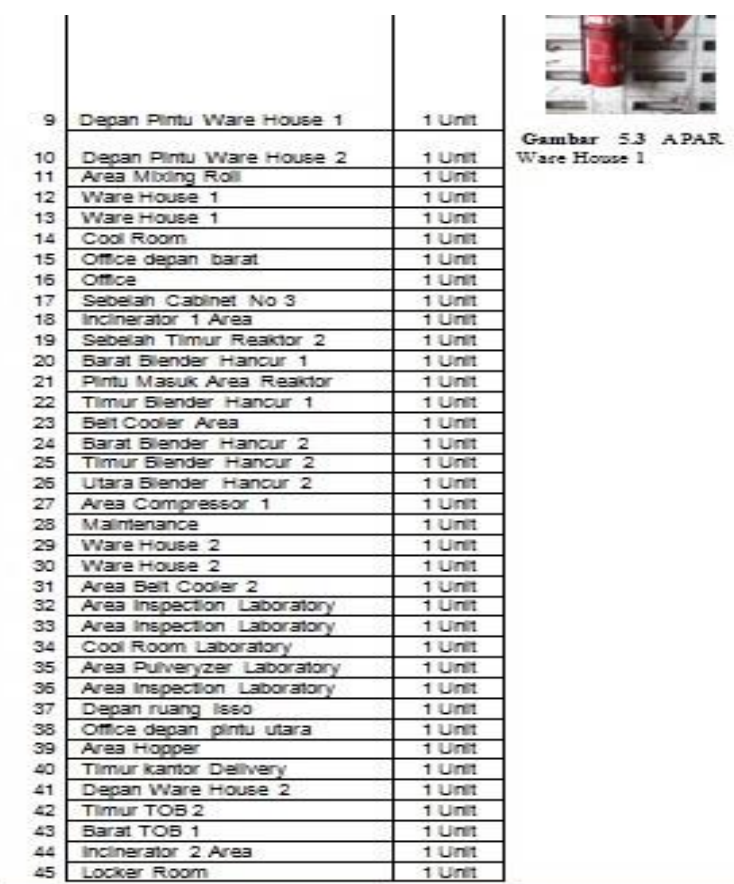

Gambar 53 APAR depan

45 Locker Room 1 Unt

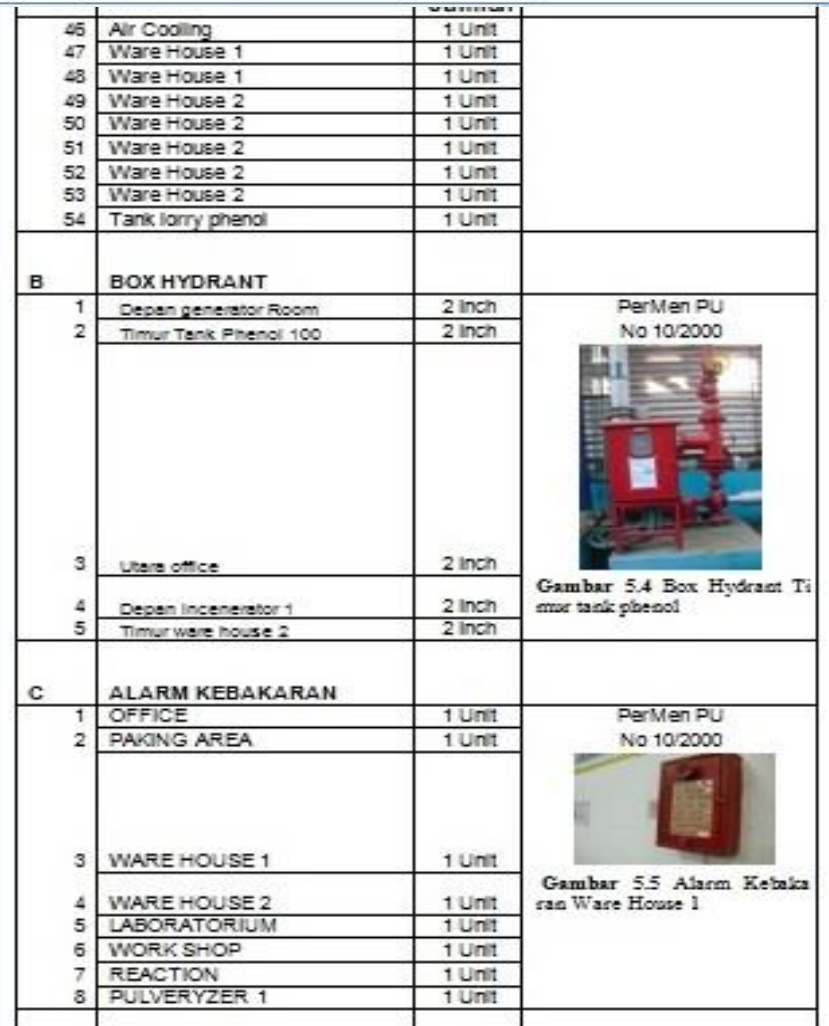




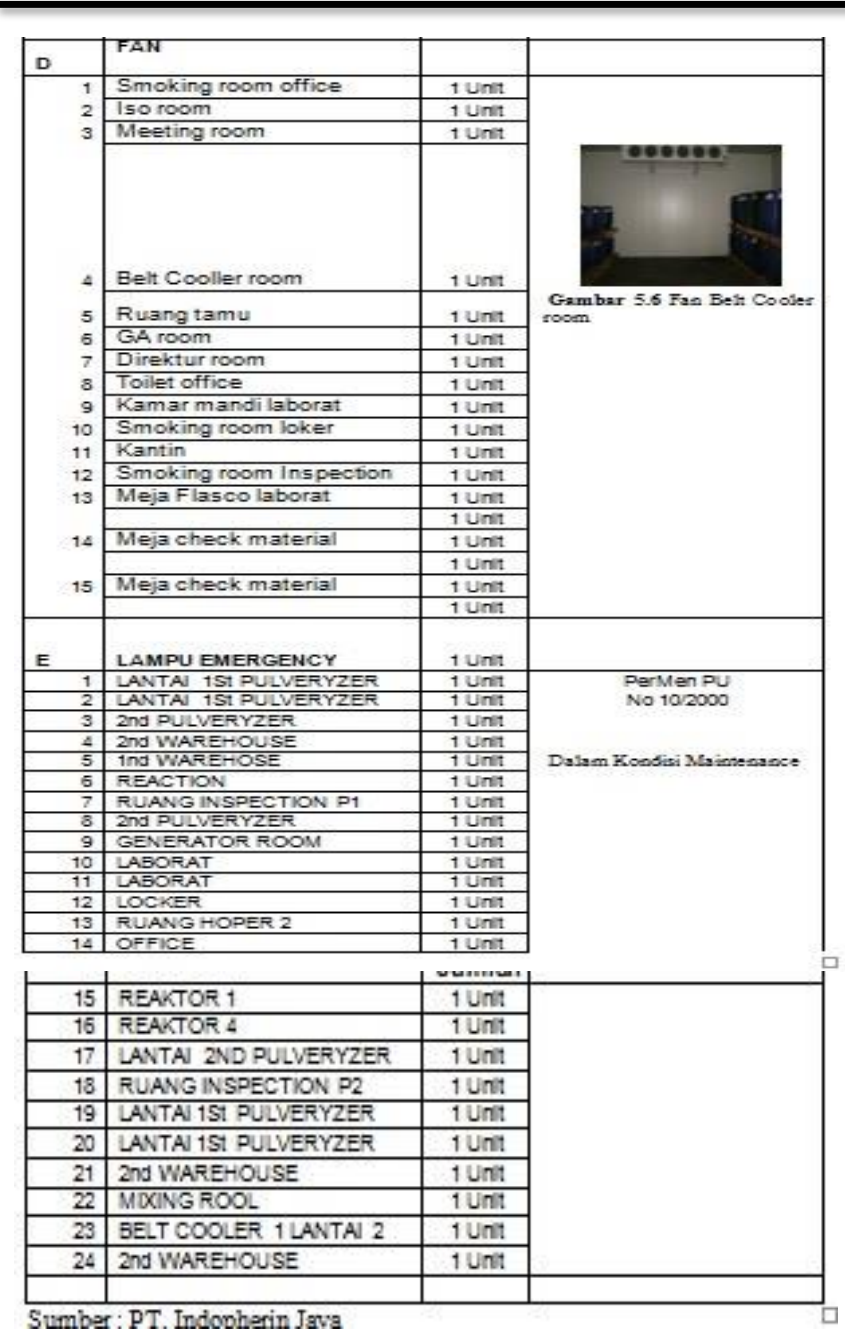

Sumber: data sekunder

Tabel 3. APD PT. Indopherin Jaya

\begin{tabular}{|c|c|c|c|c|}
\hline \multicolumn{5}{|c|}{ DAFTAR ALAT PELINDUNG DIRI dan PENGGUNAANNYA } \\
\hline \multicolumn{5}{|c|}{ No. Dokumen : :IK-KL-7.7-34 } \\
\hline Revisi & \multicolumn{2}{|l|}{$:(0) 07.05 .2013$} & \multicolumn{2}{|l|}{ Hal1 dari 2} \\
\hline \multicolumn{5}{|c|}{ Digunakan sebagai standar APD yang dipaka i di PT. Indopherin Jaya } \\
\hline No. Nama APD & Type & Spesifikasi & Kegiatan/Aktivitas & Daja Taha \\
\hline \multirow[t]{2}{*}{ Safety Shoes } & Krusher Allbany & $\begin{array}{l}\text { Ujung sepatuada a baja } 200 \text { joule } \\
\text { Sol menggunakan TPU, tahan panas } 1300 \\
\text { Memenuuhi Australiann NZ and Americans } \\
\text { footwear standards }\end{array}$ & \begin{tabular}{|l|} 
Digunakan untuk kegiatan operasional sehar 1 \\
$0 C$ \\
saffety
\end{tabular} & if 1Tahun \\
\hline & \begin{tabular}{|l|} 
AP Boots \\
9506 GR
\end{tabular} & $\begin{array}{l}\text { Material: Rubber } \\
\text { Sol rubber penthel yang ringan, bertekstl } \\
\text { halus dan lunak tapi kuat }\end{array}$ & $\begin{array}{l}\text { Digunakan pada waktu hujan,cuci ireaktor,cun } \\
\text { cuci untuk semua tanki,ireceive material B3. }\end{array}$ & 1Tahun \\
\hline \multirow[t]{2}{*}{2 Safety google } & UVEX 9301 & \begin{tabular}{|l|l} 
Perlindungan maksimum UV & Ly \\
lensa tertinggi kualitas optik - kelas 1 \\
CE menyetujui untuk EN166 $1 \mathrm{~B} 349$ \\
percikan cairan (kimia), partikel debu \\
yang besar, logam cair dan padatan.
\end{tabular} & Untuk Operasional Mising Roll. & Itahun \\
\hline & Cla Wallago & $\begin{array}{l}\text { Anti-fogging, meningkatkan Kesematan } \\
\text { Perlindungan terhadap Ultra Violet (UV) } \\
\text { Lensa ada I apisan anti gores } \\
\text { Sesuai idengan Standar ANSIZZ87.1 }\end{array}$ & $\begin{array}{l}\text { Untuk Operasional Miking Roll,operasional L } \\
\text { ory. }\end{array}$ & 1tahun \\
\hline \multirow[t]{5}{*}{ Saffety gloves } & $\begin{array}{l}\text { Neon Neoprene } \\
\text { Ansell Edmond 9.022 }\end{array}$ & \begin{tabular}{|l|l}
$\begin{array}{l}\text { Fully coated, Hirlo temperature style, } \\
12^{n} \text {, black }\end{array}$ & U. \\
\end{tabular} & Untuk operasional dengan bahan tbenda pan 1 & 1tahun \\
\hline & Towa & Liner : 13-Gauge, Seamless, Cotton TL & Untuk operasional Mixing Roll. & 6Bulan \\
\hline & \begin{tabular}{|l|} 
OR0655 \\
Sarung tangan karet sea gi
\end{tabular} & $\begin{array}{l}\text { Material: Durable PVC Warna:Bir } \\
\text { Material: Natural Rubber, Warna :Kunin L }\end{array}$ & $\begin{array}{l}\text { iru } \\
\text { Untuk operasional yang menggunakan mater } \\
\text { Limbah } \mathrm{B} \text { 3 dan proses packing }\end{array}$ & |'Minggu \\
\hline & \begin{tabular}{|l|l|} 
Sarung tangan kain Industri \\
.
\end{tabular} & & \begin{tabular}{|l|} 
Untuk operasional solid Incenerator,proses \\
di workshop dan aktifitas dil laboratorium. \\
\end{tabular} & fi Minggu \\
\hline & Sarung tangan welding & & Untuk operasional pengelasan. & 1Tahun \\
\hline 4 Sarety Helme & $\begin{array}{l}\text { MSA } \\
\text { V-Gard }\end{array}$ & $\begin{array}{l}\text { Terdiri dari cangkang polyethylene dan } \\
\text { suspensi yang bekerija bersama sebagas } \\
\text { sistem proteksi. Warna : Puth }\end{array}$ & Digunakan untuk operasional sehari-hari. & 2Tahun \\
\hline 5 Face masker & $\begin{array}{l}\text { MSA } \\
\text { Visor Faceshield }\end{array}$ & Warna : clear & \begin{tabular}{|l|} 
Untuk operasional yang menggunak an mater| \\
Limbah B3,proses packing produk liquid,pemb \\
di solid incenerator, perbaikan dengan menguv \\
gerinda,bor dan drill.
\end{tabular} & $\begin{array}{l}\text { Itahun } \\
\text { bakaran } \\
\text { unuakan }\end{array}$ \\
\hline
\end{tabular}

Sumber: data sekunder

\section{Prosedur K3}

PT. Indopherin Jaya telah memiliki berbagai prosedur mengenai $\mathrm{K} 3$ sebagai pedoman untuk terjaminnya pelaksanaan SMK3 pada area kerja. prosedur tersebut seperti kebijakan, prosedur K3, instruksi kerja, formulir, catatan serta wewenang dan tanggung jawab K3 untuk semua tingkatan dalam perusahaan.

\section{Kegiatan K3 \\ Tindakan pengendalian}

PT. Indopherin Jaya dalam melaksanakan kegiatan K3 selalu melakukan tindakan pengendalian terhadap kegiatan, produk barang dan jasa yang dapat menimbulkan risiko kecelakaan dan penyakit akibat kerja. Hal ini dilakukan melalui pemberian standar bagi tempat kerja, perancangan pabrik dan bahan, serta prosedur dan instuksi kerja untuk mengatur dan mengendalikan kegiatan produk barang dan jasa berdasarkan identifikasi potensi bahaya.

\section{Perancangan dan rekayasa}

PT. Indopherin Jaya dalam melakukan perancangan dan rekayasa selalu berdasarkan identifikasi potensi bahaya, serta pengendalian risiko kecelakaan dan penyakit akibat kerja. Selain itu personil yang memiliki kompetensi kerja khusus di bidang perancangan dan rekayasa telah ditetapkan dan diberi wewenang dan tanggung jawab khusus untuk melakukan verifikasi persyaratan SMK3. Hal ini tertuang sebagai berikut:

Tabel 4. Pemeriksaan mesin atau peralatan

\begin{tabular}{|c|c|c|c|}
\hline PEMERIKSAAI & AN & Tanggal: & \\
\hline No MESIN & & Pemeriksaan & Mengetahui \\
\hline Nama & & & \\
\hline Lokasi & & & \\
\hline Penggunaan Listrik. & & & \\
\hline 1. VISUAL & & & \\
\hline a. Suara & d. Getarar & & \\
\hline b. Karat & e. Kotor & & \\
\hline c. Kebocoran: & f. Pengam & & \\
\hline 2. LISTRIK & & & \\
\hline a. MCB pada panel & d. Ampere & : & \\
\hline b. Kondisi kabel : & e. Mergeri & ation : & \\
\hline c. Sambungan kabel & f. Panel Co & da alat: & \\
\hline h. Indicator press $/ \mathrm{T}$ & g. Inverter & : & \\
\hline 3.VALVE / CONTROLV & & & \\
\hline a. Posisi OPEN / CLO & c.Tanda a & / tidak & \\
\hline b. Handle valve terp & d. & & \\
\hline 4. OIL/Grease & & & \\
\hline a.Level Oil & b. kondisi & & \\
\hline 5. TRANMISI & & & \\
\hline a.Kondisi rantai : & b.Kondisi & & \\
\hline 6. K3L & & & \\
\hline a. Potensi bahaya & & & \\
\hline b.Dampak lingkung & & & \\
\hline c. Petunjuk/LABEL/Pe & & & \\
\hline 7.PENANGANAN ASPE & BAHAYA & & \\
\hline a. Sesuai dengan $\mathrm{Pe}$ & & & \\
\hline b. Fungsi Alarm & & & \\
\hline c. Emergency Stop & & Detik bi & Sa STOP \\
\hline d. Auto operasional & & & \\
\hline
\end{tabular}

Sumber: data sekunder 


\section{Penyerahan sebagian pekerjaan}

PT. Indopherin Jaya dalam hal penyerahan sebagian pelaksanaan pekerjaan memiliki hubungan dengan perusahaan rekanan yang bertugas mengangkut dan mengolah limbah B3 (Bahan Berbahaya dan Beracun) yakni PT. PPLI yang berlokasi di Cileungsi Bogor berdasarkan informasi dari informan.

\section{Produk akhir}

PT. Indopherin Jaya dalam menangani produk akhir berupa barang atau jasa telah menilai pula aspek K3 dari bahan yang dihasilkan. Hal ini bisa dilihat dari aspek pengemasan, penyimpanan, pendistribusian, dan penggunaan serta pemusnahannya seperti yang tertera sebagai berikut:

Gambar 10. Lembar MSD

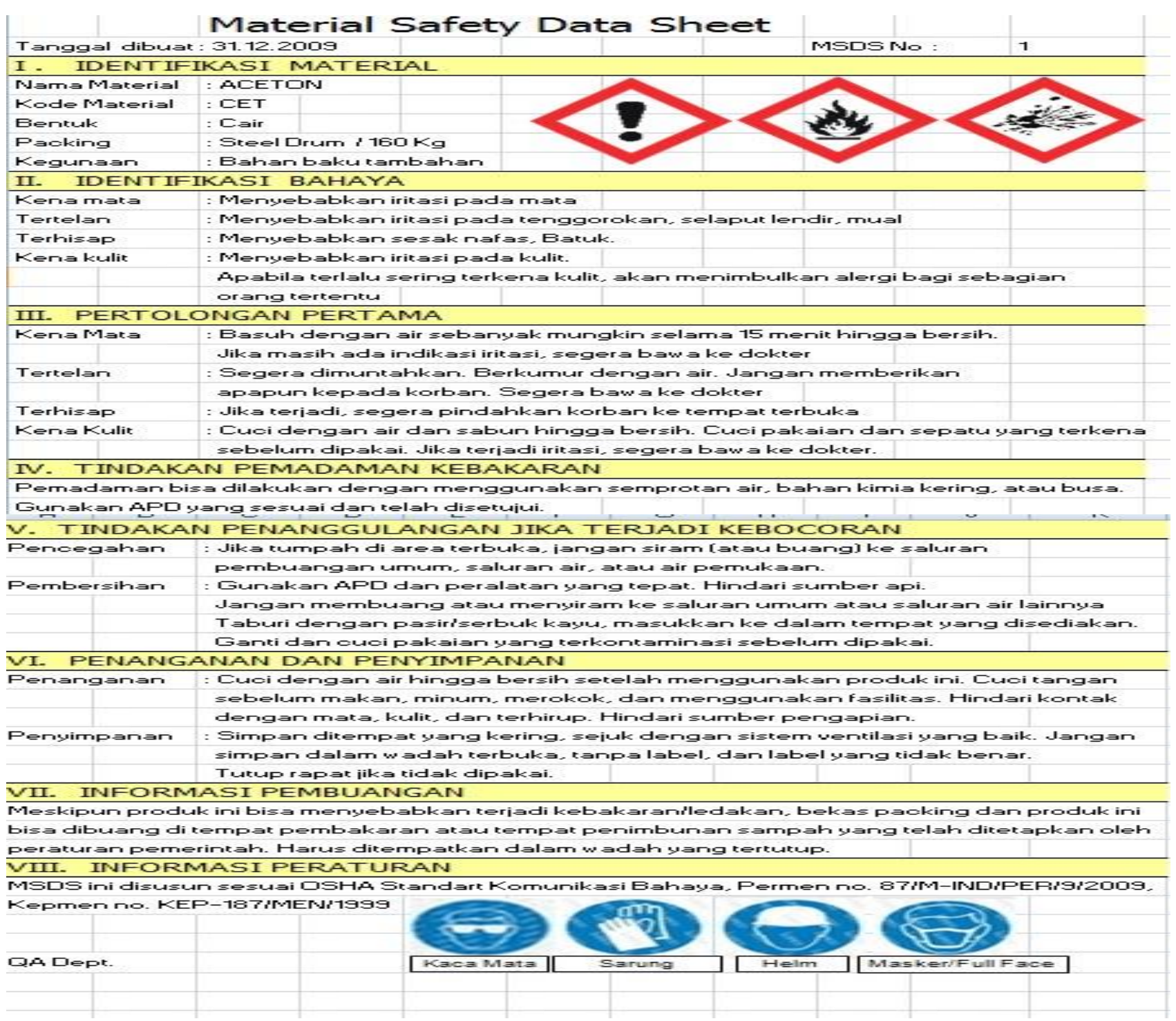

Sumber: data sekunder

\section{Upaya menghadapi keadaan darurat dan rencana} pemulihan keadaan darurat

PT. Indopherin Jaya memiliki prosedur dalam menghadapi keadaan darurat kecelakaan yang meliputi penyediaan personil dan fasilitas $\mathrm{P} 3 \mathrm{~K}$ dengan jumlah yang cukup dan sesuai sampai mendapatkan pertolongan medik untuk memperoleh proses pertolongan lanjutan di rumah sakit. Fasilitas P3K yang ada di PT. Indopherin Jaya meliputi 
JPH RECODE Vol. 1 No. 1 (2017)

Gambar 11. Kartu Stock P3K

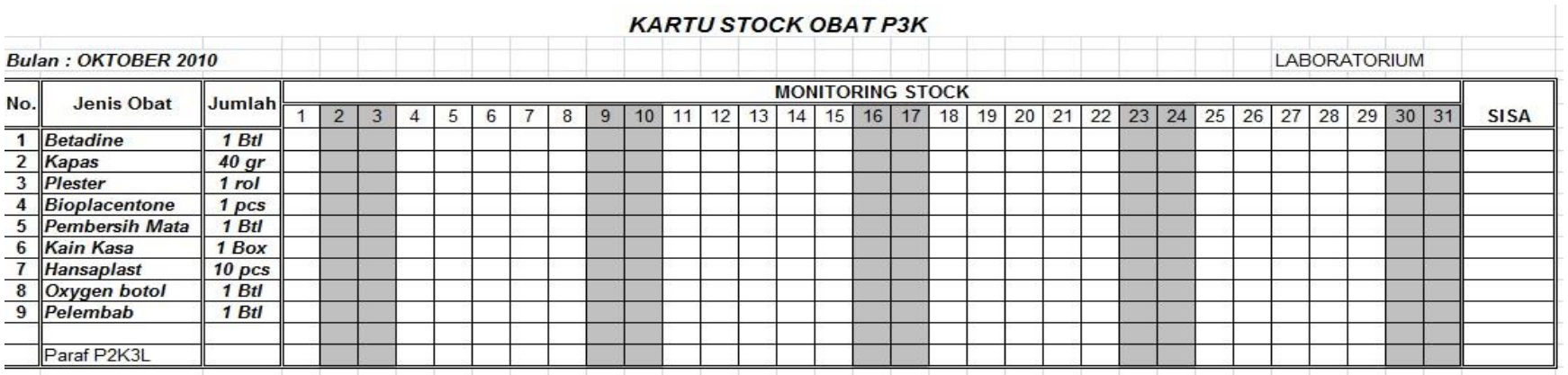

Note : *) DISI OLEH PETUGAS PIKET ( P2K3L)

Sumber: data sekunder

Prosedur dalam menghadapi keadaan darurat yang ada di

PT. Indopherin Jaya antara lain :

Gambar 12. Prosedur Tindakan darurat

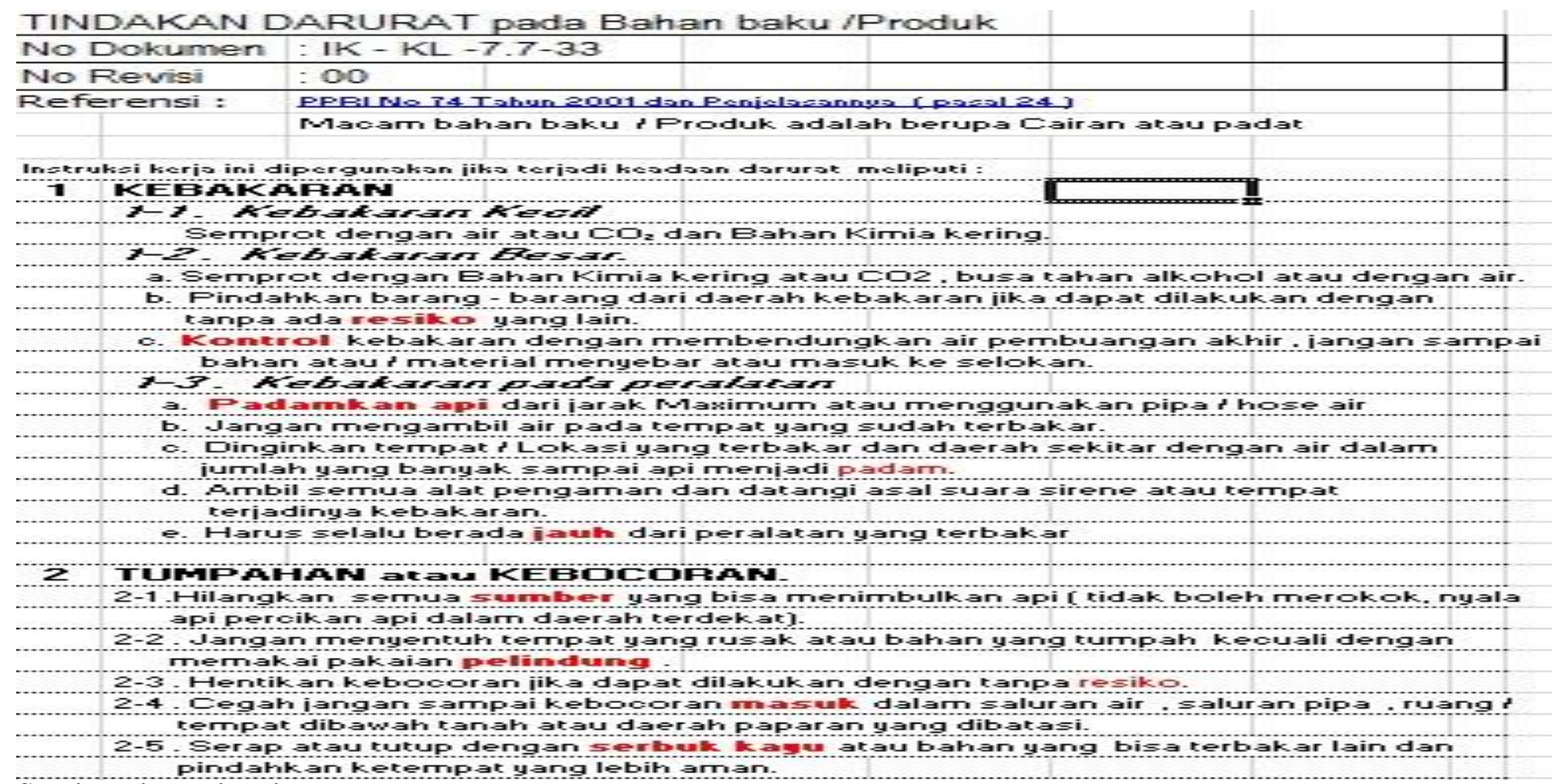

Sumber: data sekunder

Pemulihan keadaan darurat dilakukan PT. Indopherin Jaya secara cepat untuk mengembalikan pada kondisi normal dan membantu pemulihan tenaga kerja yang mengalami trauma dengan cara memberikan terapi secara fisik maupun psikologis oleh tenaga yang berkompeten.

\section{Pemantauan dan Evaluasi Kinerja K3}

Menurut responden ada hal-hal yang menjadi acuan dalam pemantauan dan evaluasi kinerja K3 di perusahaan yaitu:

Program pemantauan \& pengukuran lingkungan kerja Pemantauan dan pengukuran lingkungan kerja di PT.Indopherin Jaya dilakukan setiap 1 bulan sekali oleh
P2K3L, dengan cara melakukan plant tour kondisi lapangan dan melaporkan perbaikan yang sudah dan belum dilakukan. adapun yang diukur adalah mengenai kadar biologis (BOD), kimia (COD), fisik (TSS) total solve solid dari IPAL (Instalasi Pembuangan Air Limbah) milik PT. Indopherin Jaya.

\section{Audit internal SMK3}

Kegiatan audit internal di PT.Indopherin Jaya dilaksanakan setiap 1 tahun sekali berdasarkan persetujuan Wakil Manajemen atau manajer representatif yang menjadi sekretaris dari P2K3L. Audit internal dilakukan oleh karyawan PT. Indopherin Jaya yang diambil langsung dari lingkungan perusahaan yang tidak memiliki kepentingan dengan unit maupun bagian departemen yang akan diaudit. 


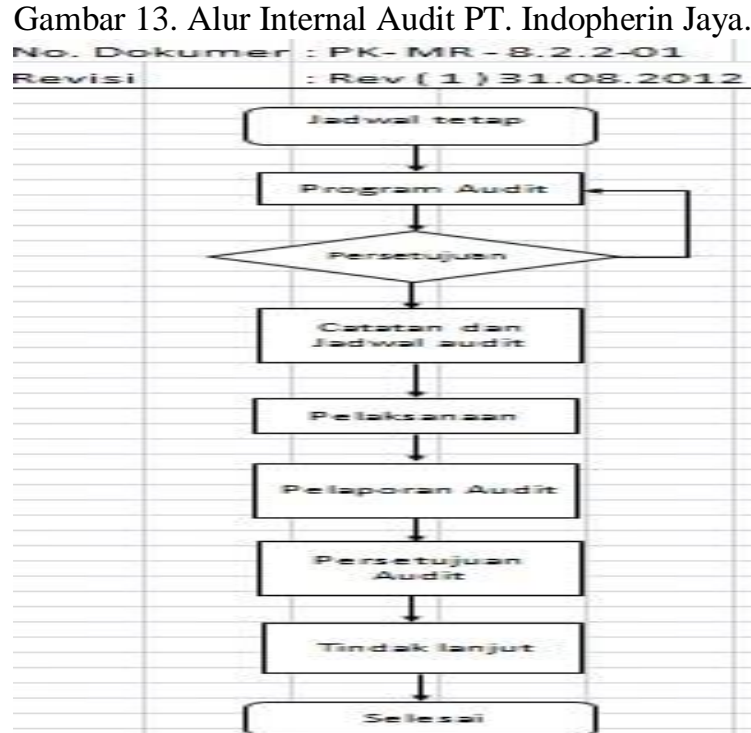

Sumber: data sekunder

\section{Peninjauan dan peningkatan kinerja SMK3}

Menurut responden PT. Indopherin Jaya dalam hal melakukan peninjauan dan peningkatan kinerja SMK3 menggunakan hasil yang telah dilakukan berdasarkan pemantauan dan evaluasi kinerja K3 yang digunakan sebagai acuan terhadap kebijakan K3, tujuan dan sasaran, serta hasil temuan audit SMK3. Selain itu dalam rangka upaya peningkatan kinerja K3 dilakukan audit eksternal setiap satu tahun sekali. Laporan hasil tindak lanjut peninjauan dan peningkatan kinerja disebarluaskan di seluruh area kerja serta diinformasikan kepada seluruh pegawai dan jajaran di perusahaan. Setelah itu dilakukan evaluasi kepada pihak top manajemen atau wakil presiden direktur sehingga dapat memberikan solusi dan upaya peningkatan kinerja K3 di perusahaan.

\section{Tinjauan terhadap elemen implementasi SMK3}

Dari keseluruhan penilaian elemen dan kriteria SMK3 berdasarkan lampiran II PP No. 50 Tahun 2012 yang tertera pada lampiran 5 mengenai lembar observasi, PT. Indopherin Jaya mendapatkan skor sebesar $95 \%$ yang tergolong ke dalam kategori memuaskan. Untuk penjelasan lebih lanjut, disajikan hasil rekap perhitungan audit SMK3 di PT. Indopherin Jaya pada tabel berikut.

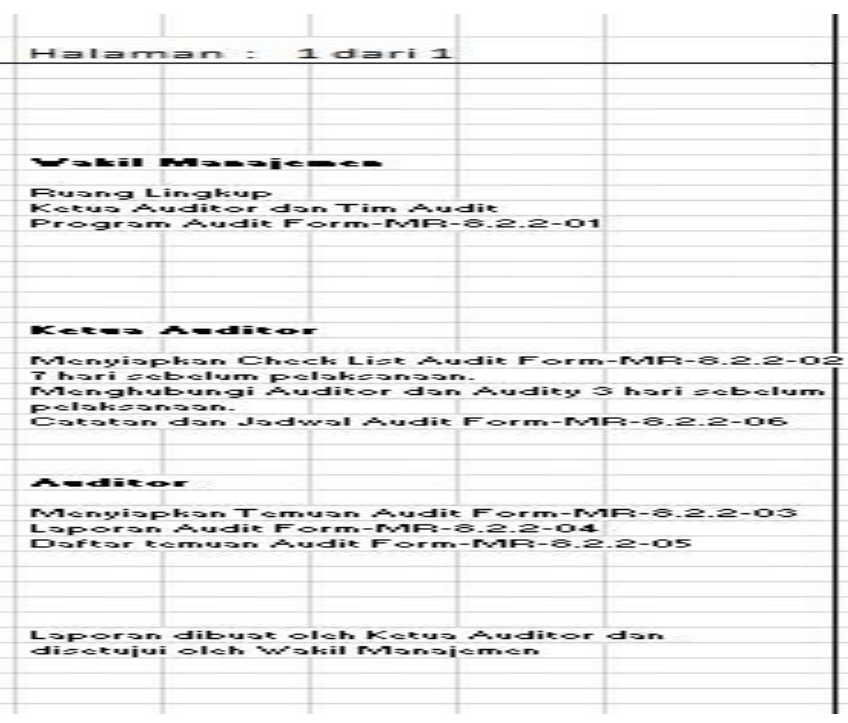

Tabel 5. Hasil Penilaian Implementasi SMK3

\begin{tabular}{|c|c|c|c|}
\hline No. & Elemen & $\begin{array}{c}\text { Kriteria } \\
\text { Maksimal }\end{array}$ & $\begin{array}{c}\text { Kriteria } \\
\text { diterapkan }\end{array}$ \\
\hline 1. & $\begin{array}{l}\text { Pembangunan dan pemeliharaan } \\
\text { komitmen }\end{array}$ & 26 & 26 \\
\hline 2. & Strategi pendokumentasian & 14 & 11 \\
\hline 3. & $\begin{array}{l}\text { Peninjauan ulang dan desain kon } \\
\text { trak }\end{array}$ & 8 & 8 \\
\hline 4. & Pengendalian dokumen & 7 & 4 \\
\hline 5. & Pembelian & 9 & 9 \\
\hline 6. & $\begin{array}{l}\text { Keamanan bekerja berdasarkan } \\
\text { SMK3 }\end{array}$ & 41 & 41 \\
\hline 7. & Standar pemantauan & 17 & 16 \\
\hline 8. & Pelaporan dan perbaikan & 9 & 9 \\
\hline 9. & $\begin{array}{l}\text { Pengelolaan material dan perpin } \\
\text { dahannya }\end{array}$ & 12 & 12 \\
\hline 10. & $\begin{array}{l}\text { Pengumpulan dan penggunaan } \\
\text { data }\end{array}$ & 6 & 5 \\
\hline 11. & Audit SMK3 & 3 & 3 \\
\hline 12. & $\begin{array}{l}\begin{array}{l}\text { Pengembangan } \\
\text { dan kemampuan }\end{array} \\
\end{array}$ & 13 & 13 \\
\hline & Total & 165 & 157 \\
\hline $\begin{array}{l}\text { Nila } \\
\text { Indo }\end{array}$ & $\begin{array}{l}\text { akhir penerapan SMK3 di PT. } \\
\text { herin Jaya }\end{array}$ & \multicolumn{2}{|c|}{$(157 / 165) \times 100 \%=95 \% \rightarrow$} \\
\hline
\end{tabular}

Sumber: data sekunder

Berdasarkan tabel diatas menunjukkan bahwa ada beberapa kriteria dari penilaian SMK3 yang masih belum bisa dipenuhi oleh PT. Indopherin Jaya elemen tersebut diantaranya yakni: Strategi pendokumentasian, Pengenda lian dokumen, standar pemantauan, serta pengumpulan dan penggunaan data.

\section{PEMBAHASAN}

Berdasarkan hasil nilai akhir audit diperoleh bahwa tingkat pencapaian penerapan SMK3 di PT.Indopherin Jaya adalah sebesar $95 \%$ yang tergolong ke dalam kategori memuaskan. Elemen yang belum dijalankan secara maksimal yakni: 


\section{Strategi Pendokumentasian}

PT. Indopherin Jaya belum memiliki data yang lengkap tentang perundangan K3 yang berlaku untuk perusahaan, menurut soehatman ramli (2013) bahwa peraturan perundangan harus diinventarisasi, dipelihara, dan diidentifikasi oleh perusahaan.

\section{Pengendalian Dokumen}

PT. Indopherin Jaya belum bisa memiliki pengendalian dokumen yang baik, sebagai bukti dokumen usang masih bisa ditemukan di beberapa tempat. Menurut lampiran I PP No. 50 Tahun 2012 bab pelaksanaan rencana K3 bagian pendokumentasian K3 huruf $e$ dan $f$ menyebutkan bahwa semua dokumen yang telah usang harus segera disingkirkan dari penggunaannya. Menurut soehatman ramli (2013) keberadaan dokumen usang di tempat kerja bisa menimbulkan keraguan dalam operasi dan berakibat fatal.

\section{Standar Pemantauan, Pengumpulan, Penggunaan Data}

Hal yang belum diterapkan berkaitan dengan elemen ini yakni belum adanya catatan pemantauan kesehatan dan rehabilitasi tenaga kerja. Menurut keputusan Direktur Jenderal Pembinaan Pengawasan Ketenagakerjaan No. KEP. 22/DJPPK/V/2008 menyebutkan bahwa tujuan utama dari pencatatan kesehatan dan rehabilitasi tenaga kerja adalah untuk mendapatkan kegiatan hasil dari waktu ke waktu, selain itu pencatatan dan pelaporan dapat digunakan sebagai umpan balik dalam beberapa kasus/masalah kesehatan kerja yang bersifat individu maupun kelompok.

\section{KESIMPULAN}

Berdasarkan hasil penelitian, dapat disimpulkan yaitu: PT. Indopherin Jaya telah memiliki kebijakan dan komitmen terhadap K3 yang telah disahkan oleh pimpinan perusahaan. Perencanaan K3 selalu dibuat berdasarkan identifikasi bahaya, penilaian risiko $\mathrm{K} 3$.

Pelaksanaan rencana K3 PT. Indopherin Jaya sudah berjalan baik. Pemantauan dan evaluasi kinerja K3 sudah dilakukan sesuai PP No. 50 Tahun 2012. Peninjauan dan peningkatan kinerja SMK3 sudah dilakukan secara rutin dan sesuai ketentuan PP No. 50 Tahun 2012. Penilaian pencapaian implementasi ada beberapa elemen yang belum diterapkan dengan lengkap yaitu: strategi pendokumentasian, pengendalian dokumen, pengumpulan dan penggunaan data serta standar pemantauan.

\section{DAFTAR PUSTAKA}

Action Plan, 2013. PT. Indopherin Jaya

Alur identifikasi bahaya,2011 PT. Indopherin Jaya

HSA, 2006. Topics/Managing Health and Safety.

http://www.hsa.ie/eng/Publications_and_Forms/Publ ications/Safety_and_Health_Management/Workplac e_Safety_and_Health_Management.pdf

HSE Training Schedule, 2014. PT. Indopherin Jaya

Keputusan Direktur Jenderal Pembinaan Pengawasan Ketenagakerjaan No. KEP. 22/DJPPK/V/2008 tentang petunjuk teknis penyelenggaraan pelayanan kesehatan kerja

ILO.2013. safe and healthy workplaces : ILO Organization.

Lembar alur Audit Internal IMS (Integrated Management System) PT.Indopherin Jaya Tahun 2013.

Lembar Identifikasi Bahaya PT. Indopherin Jaya

Lembar Kebijakan PT. Indopherin Jaya Tahun 2014

Laporan Kecelakaan kerja PT.Indopherin Jaya 1996-2013.

Peraturan Pemerintah Nomor 50 Tahun 2012 tentang Penerapan SMK3

Ramli. Soehatman. 2013. SMART SAFETY : Panduan Penerapan SMK3 yang efektif. Jakarta : Dian Rakyat

Standar Patrol, 2012. PT. Indopherin Jaya

Struktur P2K3L, 2012. PT. Indopherin Jaya 